\title{
Review on Newcastle disease in poultry
}

\author{
Koffi Francois-Xavier DZOGBEMA ${ }^{1 *}$, Essodina TALAKI ${ }^{1,2}$, Komlan B. BATAWUI ${ }^{3}$ and \\ Balabadi B. DAO ${ }^{4}$
}

${ }^{1}$ Université de Lomé, Centre d'Excellence Régional sur les Sciences Aviaires (CERSA), BP : 1515 Lomé-Togo.

${ }^{2}$ Université de Lomé, Ecole Supérieure d'Agronomie (ESA), BP : 1515 Lomé-Togo.

${ }^{3}$ Direction de l'élevage, BP : 4041 Lomé-Togo.

${ }^{4}$ Institut Togolais de Recherche Agronomique (ITRA), BP : 1163 Lomé-Togo.

*Corresponding author; E-mail: dzofrance98@yahoo.com; Tel: 0022891561565

\begin{tabular}{ccc}
\hline Received: 14-11-2020 & Accepted: 01-03-2021 & Published: 30-04-2021 \\
\hline
\end{tabular}

\begin{abstract}
Newcastle disease is an infectious disease of poultry caused by an avian Paramyxovirus type I that affects more than two hundred avian species. It is an enzootic disease in parts of Asia, Africa, the Middle East and some countries in South America. Isolated outbreaks of Newcastle disease occur sporadically in some European countries and Central America. This review synthesizes available information on the virus and the disease it causes. The disease is transmitted by direct contact with infected animals or by indirect contact through inanimate carriers. The incubation period of the disease varied from 2 to 15 days. Five pathotypes were distinguished according to the incidence and severity of the clinical signs. Velogenic strains, which are the most virulent, can cause $100 \%$ mortality in unprotected herds. Control measures are based on mass vaccination of susceptible animals and the application of biosecurity measures in poultry farms. Regulations are also put in place to prevent the introduction of the virus into countries free of the disease.
\end{abstract}

(C) 2021 International Formulae Group. All rights reserved.

Keywords: Poultry, paramyxovirus, Newcastle disease, panzootie, mortality.

\section{INTRODUCTION}

Newcastle Disease also known as pseudo-fowl plague, refers to all infections of poultry caused by avian paramyxovirus serotype 1 (APMV-1). It is a highly contagious viral disease that can affect a large number of avian species and cause severe economic losses. The Newcastle disease virus can infect more than two handred different species of birds (Rauw et al., 2009). This disease is capable of causing $100 \%$ mortality in unprotected bands. It is entered on the list of diseases requiring notification to the World
Organisation for Animal Health (OIE). It is defined by the OIE as an infection disease of poultry caused by an APMV-1, which has an intracerebral pathogenicity index (ICPI) in day-old chicks (Gallus gallus) of 0.7 or greater and also has multiple basic amino acids at the $\mathrm{C}$-terminus of the $\mathrm{F} 2$ protein and phenylalanine at residue 117 , which is the $\mathrm{N}$-terminus of the F1 protein (OIE, 2018). The term multiple basic amino acids refers to at least three arginine or lysine residues between residues 113 and 116 (Swayne and King, 2003; Youn et al., 2004; OIE, 2018). Newcastle disease has 
been identified as a major constraint to the development of poultry farming. Its impact is more disastrous in developing countries where traditional poultry farming is dominant and represents an important source of income and animal protein for households. This review synthesizes available information on the virus and the disease it causes.

\section{HISTORY OF THE DISEASE}

The first outbreak of Newcastle disease occurred in 1926 in Java, Indonesia (Kraneveld, 1926) and in Newcastle on Tygne in Great Britain, from which it takes its name (Doyle, 1927). It was also described the same year in Korea (Kraneveld, 1926). However, there may have been previous manifestations of the disease (Alexander et al., 2012).

Between 1926 and 1981, four Newcastle disease panzooties occurred around the world. The first panzootic outbreak of the disease occurred 20 years after its discovery, following numerous isolated outbreaks in several countries around the world. The second panzootic outbreak appeared to have started in the Middle East in the late 1960s, and spread faster than the first and affected almost every continent. This episode of the disease was facilitated by the major revolution in the poultry sector in the aftermath of the Second World War, which transformed the poultry industry into a commercial industry with an international scope. During this episode, the disease was introduced into some countries by air transport of wild bird species (Francis, 1973; Walker et al., 1973; Lancaster, 1975). The severity of the second panzootic disease led to the development of vaccines that provided significant protection for poultry (Walker et al., 1973). The universal use of live vaccines has facilitated the introduction of the virus into disease-free areas. The viscerotropic velogenic strain of the virus was responsible for the third panzootic disease outbreak, which lasted from 1968 to 1972. However, antigenic and genetic data on the virus did not establish the facts that led to the emergence of this third pandemic. The fourth panzootic occurred from 1980 onwards and began in the Middle East. It primarily affected racing pigeons and other domesticated pigeons, but later spread to wild pigeons and other poultry. It spread easily and was difficult to control because it affected animals that were susceptible to Newcastle disease virus and were not included in the vaccination program.

The history of the origin and distribution of the disease in Africa remains poorly documented. The first description of the disease in Africa dates back to the end of World War II in 1945 when it decimated several poultry flocks in South Africa and spread throughout this country (Gear, 1986). It then appeared in Madagascar a year later around a rail transport network where several outbreaks occurred. The importation of fighting cocks and other poultry birds from South Africa was blamed for the introduction of the disease into Madagascar (Rajaonarison, 1991; Maminiaina, 2011). In Ethiopia, it was believed to have appeared in 1971 and was caused by a velogenic strain (Lefevre and Martel, 1975). The first appearances of the disease in West, North and East Africa remain unknown. It is likely that it appeared in this region at the end of and after the Second World War through wild birds, transport and trade in poultry but this remains to be proven. However, years after the first description in South Africa, several serological studies carried out confirmed the presence of the disease in several countries on the continent: Nigeria (Ezeokoli et al., 1984); Niger (Courtecuisse et al., 1990); Tanzania (Minga et al., 1989) ; Cameroon (Agbede et al., 1992); Benin (Spradbrow, 1992); Togo (Grundler et al., 1988). Outbreaks have also been reported in many countries throughout the continent. These include Sudan, Morocco, Burundi, Uganda, Burkina Faso, Côte d'Ivoire, Mauritania and Mozambique (Kim et al., 2012). In 1955, the virus was classified in the family Paramyxoviridae, genus Avulavirus. It has become an OIE notifiable disease since then. Thirty-one (31) African countries covering West, East, Southern and Northern Africa have reported Newcastle disease to the Inter-African Bureau for Animal Resources of the African Union in 2011 (Pan African Animal Resources, 2013) and to date, the disease is enzootic in 33 African countries. In 
2019, the OIE recorded 25 notifications of new outbreaks of Newcastle disease in 25 African countries (OIE, 2020).

\section{ETIOLOGY}

The pathogen responsible for the disease is called Newcastle Disease Virus or avian paramyxovirus type-I (APMV-I). It is a virus belonging to the order Mononegavirales, subfamily Paramyxovirinae, family Paramyxoviridae and genus Avulavirus. (Alexander, 1988; Abdisa and Tagesu, 2017). This family of Paramyxoviridae contains 9 serotypes (Rauw et al., 2009) and Newcastle disease virus belongs to serotype 1 . Serotypes 2, 3, 6 and 7 (APMV-2; APMV-3; APMV-6 and APMV-7) are also known to cause diseases in poultry. Depending on the incidence and severity of clinical signs, 5 pathotypes or strains are distinguished: (i) apathogenic strains, (ii) lentogenic strains, (iii) mesogenic strains, (iv) viscerotropic velogenic strains and (v) neurotropic velogenic strains (Alexander and Senne, 2008). Although all Newcastle diseases are members of APMV-1 and belong to the same serotype, antigenic and genetic diversity is observed between the different genotypes (Miller and Koch, 2013). A complete analysis of the Newcastle disease virus genome revealed three genome sizes divided into two classes I and II (Courtney et al., 2012; Diel et al., 2012; Miller and Koch, 2013). Class I contains avirulent strains of the virus with a genome size of 1598 nucleotides, while Class II contains both virulent and avirulent strains with genomes size of 1586 or 1592 nucleotides. There were 9 genotypes within class I (Diel et al., 2012) and 18 genotypes within class II (Kim et al., 2012). In addition, sequencing of the fusion protein $\mathrm{F}$ gene identified six (6) distinct lines of Newcastle disease virus (Aldous et al., 2003). Epidemiological studies have revealed that genotypes V, VI and VII of Newcastle disease virus class II strains are the most widespread genotypes currently circulating in the world. Among these, genotype VII has been associated with many recent epidemics in Asia, Africa, the Middle East and South America (Kim et al., 2012; Miller and Koch, 2013).
Genotypes II and IV have been identified in North America (Czeglédi et al., 2006) and Europe (Locke et al., 2000).

\section{STRUCTURE AND ORGANIZATION OF THE VIRUS GENOME}

The Newcastle Disease virus is an enveloped RiboNucleic Acid (RNA) virus that generally has a spherical shape that can vary and present a filamentous form (Yusoff and Wen Siang Tan, 2001). It has a diameter ranging from $100 \mathrm{~nm}$ to $500 \mathrm{~nm}$. Like viruses of the order Mononegavirales, APMV-1 are single-stranded non-segmented RNA viruses of negative polarity with a capsid of helical symmetry (Lamb and Kolakofsky, 1996). The Newcastle disease virus genome consists of six 3'-NP-P-M-F-HN-L-5' organized structural genes that code for six major polypeptides: Nucleoprotein (N), Phosphoprotein (P), Matrix protein (M), Fusion protein $(\mathrm{F})$, Hemagglutinin-Neuraminidase (HN) and Large protein (L) (Chambers et al., 1986; Lamb and Griffith, 2001; Czeglédi et al., 2006). Protein F, $\mathrm{HN}$ and $\mathrm{M}$ are integral parts of the viral envelope or peplos. Protein F and HF are anchored in the lipid bilayer, which forms the outer envelope of the virus. Just below the lipid bilayer is the outer layer of the envelope, which is formed by the M protein.

Nucleoprotein $(\mathrm{N})$ is a polypeptide consisting of 489 amino acids with a molecular weight of $53 \mathrm{KDaltons}$. It is the most abundant of the protein and protects the viral genome against the nucleasic activities present in the host cells (Kho et al., 2003).

Phosphoprotein (P) has a molecular weight of 42 Kdaltons and is composed of 395 amino acids (Yusoff and Wen Siang Tan, 2001). It is part of the APMV-1 transcriptase replicase complex and is a cofactor of the viral polymerase. Together with RNA polymerase, phosphoprotein plays a central role in genome replication and transcription (Hamaguchi et al., 1985) and in stabilizing the P-L complex. The $P$ gene can be transcribed into two other nonstructural proteins, $\mathrm{V}$ and $\mathrm{W}$. These are involved in viral regulation and expression and interfere with the antiviral cellular response (Gotoh et al., 2001; Jang et al., 2010). 
The Matrix Protein (M) consists of 346 amino acids. It is a basic protein with several conserved hydrophobic regions (Bellini and al., 1986). It coats the inner surface of the viral envelope membrane and binds to the $\mathrm{N}$ terminal region of the $\mathrm{HN}$ glycoprotein (García-Sastre et al., 1989). The M protein is considered to be the central organiser of virion morphology and assembly. It interacts with both the nucleocapsid and cytoplasmic domains of the $\mathrm{HN}$ and $\mathrm{F}$ glycoproteins. It is involved in ribonucleoprotein compaction, mainly in the viral assembly and budding stages (Iwasaki et al., 2009). The M protein could thus block the export of messenger RNA and inhibit the expression of host cell genes (Kopecky and Lyles, 2003; Maminiaina, 2011).

The Fusion Protein (F) contains 553 amino acids with a molecular weight of 55 KDaltons (Chambers et al., 1986; Seal et al., 2005). It is synthesized and glycolysed in the endoplasmic reticulum as an inactive F0 precursor (Yusoff and Wen Siang Tan, 2001). It becomes active after cleavage by specific cell proteases within the Golgi apparatus (Nagai et al., 1976; Ogasawara et al., 1992; Gotoh et al., 2001). The activated protein $F$ is composed of 2 cleaved F1 and F2 subunits linked by a disulfide (-S-S-) bridge (Bossart et al., 2009). It is this cleaved form that is capable of initiating cell fusion. The cleavage site is located between positions 112 and 117 of the fusion protein precursor (Bossart et al., 2013). This cleavage site forms the molecular basis for the pathogenicity of APMV-1 (RömerOberdörfer et al., 2003). Velogenic and mesogenic strains have a cleavage site formed by at least 3 basic amino acids, arginine (R) lysine $(\mathrm{K})$ and phenylalanine $(\mathrm{F})$ at position 117 (Peeters et al., 1999; Römer-Oberdörfer et al., 2003; de Leeuw et al., 2005). This type of site is cleaved by furin-like enzymes that are ubiquitous in the body, whereas the cleavage sites at two basic amino acids are cleaved only by trypsin-like enzymes located in the digestive and respiratory mucosa (Tashiro et al., 1992). This difference explains why virulent strains are more invasive and cause systemic disease in the infected organism. The role of the fusion protein $(\mathrm{F})$ is to ensure the fusion of the viral envelope with the cell membrane when the virus penetrates the target cell (Smith et al., 2009). This fusion takes place after activation by the attachment of the HN protein to cellular receptors. When activated, the $\mathrm{F}$ protein also fuses contiguous cells during the passage of virions from cells to syncytiumforming cells (Hernandez et al., 1996; Seth et al., 2007; Yamakawa et al., 2007).

Hemagglutinin-Neuramidase (HN) is a type II transmembrane glycoprotein where the $\mathrm{N}$-terminus is fixed in the virus envelope (Bossart et al., 2009). It has a molecular weight of approximately 53 KDaltons (Yusoff and Wen Siang Tan, 2001). The primary structure of the HN oligopeptide contains $571 ; 577 ; 581$ or 616 amino acids (Römer-Oberdörfer et al., 2003). Hemagglutinin Neuramidase proteins with 616 amino acids are found in avirulent APMV-1, while the 581 and 577 amino acids are present in both virulent and avirulent strains. Peptides containing 571 amino acids are only found in virulent strains of APMV-1 (Römer-Oberdörfer et al., 2003). The hemagglutinin neuramidase protein of Newcastle disease virus is a multifunctional protein (Huang et al., 2004). It is the major antigenic determinant of the virus (Panda et al., 2004). It possesses both Hemagglutinating (HA) and Neuraminidase (NA) activity (Scheid and Choppin, 1974; Kawano et al., 1990) and ensures the attachment of the virus to receptors on target cells. During the release of neosynthetic viruses, the NA activity of the HN protein allows the binding between hemagglutinin and sialic acid in the host cell to be cleaved (Von Itzstein et al., 1993; Gubareva et al., 1995). Thus, viruses do not interact with their receptors at the producer cell level and can release it to begin their dissemination steps.

The Large Protein (L) is the largest and least abundant of the APMV-1 structural proteins composed of 2204 amino acids. It weighs 249 KDaltons (Yusoff and Wen Siang Tan, 2001). In association with the $P$ and $N$ proteins, the $\mathrm{L}$ protein provides all the catalytic activities of the viral polymerase associated with transcription and replication (Hamaguchi et al., 1985; Lamb and Griffith, 2001). 


\section{VIRAL CYCLE}

The spread of paramyxoviruses in the organism of infected species follows the steps in the following chronological order: the first step is the penetration of the virus into the target cells. Through the proteins of the outer envelope, the virus enters the target cell. The $\mathrm{HN}$ protein mediates cell attachment, while the $\mathrm{F}$ protein is required for cell fusion (Smith et al., 2009). The HN protein binds to the host cell surface through sialic residues on the cell surface (Suzuki et al., 1985; Maminiaina, 2011). After fusion of the virus envelope with the host cell membrane, the viral nucleocapsid is released into the cytoplasm. This is followed by the transcription phase of the viral genome.

The RNA-dependent RNA polymerase transcribes the leader RNA and each of the viral genes into individual 5'-capped and 3'polyadenylated mRNAs according to a transcription gradient (Whelan et al., 2004). This leads to the production of more mRNA transcripts from the genes closest to the promoter region compared to the genes closer to the $5^{\prime}$ end. The individual mRNAs are then translated into viral proteins. Once a sufficient number of viral proteins are produced, transcription stops and replication follows. Replication produces a complete anti-genome of negative-sense RNA in combination with the $\mathrm{N}$ protein. Each of the $\mathrm{N}$ subunits is associated with 6 nucleotides of genomic RNA and thus adheres to the "rule of six" of most paramyxoviruses (Peeters et al., 2000). This characteristic is the reason why the genome size of all Newcastle disease viruses is always a multiple of six. After the replication phase of the viral genome, the budding process begins. The nucleocapsids assemble in the cytoplasm of the host cell with initial binding of the $\mathrm{N}$ protein to RNA to form a helix, followed by the integration of the $\mathrm{P}$ and $\mathrm{L}$ proteins (Lamb and Griffith, 2001). The nucleocapsids are then transported to the plasma membrane and are bound to the surface glycoproteins $\mathrm{F}$ and $\mathrm{HN}$ via the $\mathrm{M}$ protein.

During this phase, the viral envelope is also put in place. And finally the new viral particles are released from the cells. During the release of infectious viral particles, the $\mathrm{HN}$ protein intervenes to eliminate sialic acid receptors through its neuraminidase activity (Smith et al., 2009).

In addition, the virus can also spread in the host organism by forming giant multinucleated cells called syncytia by fusion between an infected cell expressing the glycoproteins $\mathrm{HN}$ and $\mathrm{F}$ and a neighbouring cell (Ahamed et al., 2004; Maminiaina, 2011).

\section{EPIDEMIOLOGY}

\section{Host species}

Newcastle disease virus is capable of infecting more than 200 different species of poultry (Rauw et al., 2009). Newcastle disease infections have been established in 241 bird species representing 27 orders of the bird class (Alexander, 2000). Chickens are the most susceptible species, followed by turkeys. Wild birds are considered reservoirs of the virus. Pigeons, however, are infected with a pigeon paramyxovirus (PPMV).

\section{Transmissions}

The disease can be transmitted to healthy poultry through direct or indirect contact. Transmission through direct contact occurs mainly through ingestion or inhalation of secretions from the respiratory tract, mouth, cloaca or eyes of infected animals. Birds vaccinated against Newcastle disease virus can excrete virus particles over a period ranging from 4 (Utterback and Schwartz, 1973) to 12 months (Allan et al., 1980). Indirect contact transmission occurs through contaminated feed, husbandry equipment and transport equipment. Farm personnel may also act as intermediaries by carrying the virus on their clothing and footwear. The virus can also be carried in the air from an infected poultry house or in an infected place to a free area. It has been shown that the virus can be transported over a distance of 64 meters (Hanson and Spalatin, 1978). Chicks can also be infected during handling at hatching when the virus is present on the shell surface.

In traditional rearing systems, eradication of the disease remains difficult because of the regular contact of domestic poultry with potentially infected wild birds, 
which represents a continuous and unpredictable risk of virus spread. In addition, the husbandry practices represent an obstacle to the eradication of the disease. Roaching of poultry, the association of several species in the same backyard (species with different susceptibilities to the virus), the presence of animals of different ages, low vaccination coverage, the introduction of new birds into the backyard without quarantine observation, and the sale of already infected birds are also significant risk factors in the spread of the disease (Maho et al., 2004). In addition, authors have reported significant seasonal variations in the prevalence of the disease in tropical areas (Arbelot et al., 1997; Orajaka et al., 1999; Manchang et al., 2004; Nwanta et al., 2008). The incidence of the disease is higher in dry seasons than in the rainy season (December, January, February and March). During this period, the climate is dry, cold and windy. This suggests that the wind speed and the large amount of dust in the air during this period may have influenced the spread and transmission of the disease (Halle et al., 1999; Abdu et al., 2007).

\section{Susceptibility of the virus}

Heat and ultraviolet treatment results in a reduction in virulence or inactivation of viruses. The thermal stability of Newcastle disease isolates is variable and depends on the virus strain (Hanson et al., 1949). This characteristic has provided a rapid method for distinguishing pathogenic from apathogenic strains in epizootiological studies. Slowogenic strains are more easily inactivated at $56{ }^{\circ} \mathrm{C}$, whereas virulent strains are more resistant at this temperature (Hanson and Brandly, 1955). Newcastle disease virus is inactivated at $56{ }^{\circ} \mathrm{C}$ for 3 hours or at $60{ }^{\circ} \mathrm{C}$ for 30 minutes (OIE, 2014). Viruses are also inactive at acidic $\mathrm{pH}$ $(\mathrm{pH} \leq 2)$ and are sensitive to certain chemicals such as ether, formalin, phenol and 6\% sodium hypochlorite (OIE, 2014). The virus can survive for long periods at room temperature. This survival is prolonged when it comes to organic matter, specifically faeces.

\section{Clinical signs}

The virulence of APMV-1 varies widely depending on the viral strains and the symptoms observed in infected birds are a function of the viral strain of the host species (Rauw et al., 2009), the age of the animal, the immune status, the dose of infection and the route of infection. The incubation period after natural exposure to viruses ranges from 2 to 15 days with an average of 5 to 6 days (Hanson and Spalatin, 1978). In unprotected herds, and depending on the strain present, abrupt and high mortalities of up to $100 \%$ can occur in susceptible individuals (Alexander et al., 2012). Lentogenic strains cause only a mild respiratory infection. Mesogenic strains have intermediate virulence causing respiratory distress and low mortality. Neurotropic velogenic strains cause neurological (torticollis, clonia, paralysis of legs and wings) and respiratory (cough, rales) disorders, and viscerotropic strains cause much more greenish-colored diarrhea and digestive disorders. In addition to the clinical signs mentioned above, infected chickens usually show depression, prostration, oedema around the eyes, decreased or stopped laying, cyanosis of the crest, and swelling of the head.

\section{Lesions}

Necropsy of birds infected with the viscerotropic velogenic strains of the virus reveals haemorrhagic lesions in the digestive tract (proventriculus and small intestine, ceaca), an enlarged and mottled spleen. In the presence of neurotropic velogenic strains, inflammation and hemorrhage of the trachea is observed with the secretion of purulent exudates from the bronchioles. This pathotype also leads to neuronal degeneration. Significant lesions are often observed in the caudal central nervous system (spinal cord, brain stem). However, they are minimal in the brain. Both mesogenic and velogenic strains have the ability to invade neural tissue, but the replication rate of mesogenic viruses is comparatively slower. In chicken embryos, infection with Newcastle disease virus leads to a change in the protein profile, with 
haemorrhages on all parts of the body (Qosimah et al., 2018).

\section{Differential diagnosis}

During epidemiological diagnosis in the field and even after autopsy, misdiagnosis may occur and Newcastle disease may be confused with several other pathologies because there are no pathognomonic signs to the disease. For this reason, the diseases with which Newcastle disease shares the same symptoms are eliminated. The clinical signs and the evolution of the signs caused by virulent strains may strongly resemble those of many diseases such as: Highly Pathogenic Avian Influenza (Terregino and Capua, 2013), Infectious Bronchitis (Lancaster, 1981), Avian Cholera, Acute Infectious Laryngotracheitis, Diphtheria, Avian Smallpox, Septicaemic Infections, Acute Poisoning or mismanagement (deprivation of water, air, food). In pigeons it can be confused with salmonellosis or ornithosis (Terregino and Capua, 2013). Despite the differential diagnosis, laboratory analyses are necessary for a definitive and accurate diagnosis.

\section{LABORATORY METHODS FOR NEWCASTLE DISEASE DIAGNOSIS Indirect methods}

They include all the serological tests used for the diagnosis of the disease. The serum is collected after centrifugation of blood collected from the wing vein of the poultry or according to the technique described by Maminiaina (2011), which consists of allowing the collected blood to rest for $30 \mathrm{~min}$ to 1 hour at room temperature and then collecting the serum. Indirect testing methods consist of detecting antibodies in the serum of animals exposed to the virus or vaccinated animals. The presence of antibodies specific to Newcastle virus in unvaccinated animals does not indicate a common infection at the time of collection, but indicates that the subject at some time has been in contact with the virus. However, a high serum antibody titer indicates recent infection. For example, a titer of $\log 26$ or higher suggests recent infection with the virus. If no vaccination has been carried out, the diagnosis of infection can be made on this basis, although it is impossible to determine exactly when the infection occurred (Getabalew et al., 2019). Sequential sampling may indicate the chronological variation in antibody titer that may or may not result from infection. In vaccinated birds, a $\log 23$ titer indicates protection. The limitation of serological tests is that they provide no information on the viral strain and do not differentiate between postinfection and post-vaccination antibodies. Two types of tests are described by the OIE for the serological diagnosis or evaluation of Newcastle disease vaccination programmes. The Haemagglutination Inhibition test (HI) and the Enzyme Linked Immuno Sorbant Assay (ELISA). The HI and ELISA tests detect or measure antibodies to Newcastle disease antigens.

\section{Hemagglutination Inhibition test (HI)}

This is the most commonly used reference test. It is based on the reaction between the virus and a specific antiserum. The principle of the reaction is that haemagglutinin on the viral envelope can cause agglutination of red blood cells of the host species and that these can be inhibited by specific antibodies (Getabalew et al., 2019). When the antiserum reacts with the virus, it binds to the antigenic determinants responsible for haemagglutination; therefore, these will not be available to bind to red blood cells. If the antiserum is not specific for the virus, haemagglutination will indicate non-identity between the two reagents i.e. in the absence of any specific antibody to the virus, haemagglutination will not occur. Standardised protocols for the haemagglutination inhibition test are described by some authors (Terregino and Capua, 2013; OIE, 2018).

\section{Enzyme Linked Immuno Sorbent Assay (ELISA)}

The ELISA test is used for the detection and quantification of antibodies. In the case of antibody detection, the antibodies bind to the viral antigens on the microtiter plate, which is picked up by second so-called detection antibodies produced in another species against 
antibodies in chickens. These antibodies couple to an enzyme which catalyzes the reaction, causing a change in color which is then quantitatively observed on a photoelectric spectrometer designed to read the microtitration of the plates.

A range of commercial ELISA kits are available, based on several principles for the detection of Newcastle disease virus antibodies. These are the indirect ELISA, sandwich ELISA and competition ELISA (OIE, 2018). It is possible to detect antibodies of more than one antigen of the virus with ELISAs but not all variants of ELISAs allow this. Competitive ELISAs may not recognize all strains of APMV-1 if they use monoclonal antibodies known to be specific for unique epitopes. Comparative studies have shown that ELISAs are reproducible and have high sensitivity and specificity (Brown et al., 1990).

\section{Direct methods}

Direct diagnostic methods are based on the isolation and identification of the virus from biological samples taken from a host infected with the virus. The presence of the virus in certain organs depends on the virus strain. Some viral strains may be found in some organs and others may not. For example, velogenic strains can be isolated from the brains of infected birds while mesogenic strains cannot (Alexander, 1988, 1995; Roy, 2012). The OIE recommends that the isolation of Newcastle disease virus from tracheal and cloacal swabs should be taken from live animals (OIE, 2018). The virus can also be isolated from lacrimal secretions. In recently dead animals isolation can be performed from organs such as liver, proventriculus, spleen, brain, intestines, ceaca (Alexander, 1995; Roy, 2012), kidneys, lungs and heart tissue. It is also possible to perform oropharyngeal swabs on cadavers. These swabs or organs are placed in PBS (phosphate buffered saline) solutions containing antibiotics and adjusted to a $\mathrm{pH}$ of approximately 7 . These samples are then stored at $4{ }^{\circ} \mathrm{C}$ if the samples are to be analysed within a short time or at least at $20^{\circ} \mathrm{C}$ if they are to be analysed much later.

\section{Viral isolation}

Before viral isolation, RNA is extracted first. There are several methods for manual or automatic RNA extraction. Many kits are commercially available and some are developed and optimized for the extraction of nucleic acids from specific samples such as tissue, blood or feces (Terregino and Capua, 2013). The conventional isolation technique recommended by the OIE is carried out on embryonated eggs from Specific Pathogen Free (SPF) chickens. An injection of a viral suspension is carried out on embryonated eggs that have been incubated for nine days. From 24 hours after the injection, the eggs containing the dead embryos are refrigerated at $4{ }^{\circ} \mathrm{C}$ and then the allantoic liquid is collected for testing.

\section{Virus identification}

The conventional method of identifying the viral strain of the disease is Reverse Transcriptase Polymerase Chain Reaction (QRT-PCR) followed by real-time PCR. It is a technique that amplifies the cleavage site of the fusion gene for rapid identification of the viral strain (Creelan et al., 2002). Tracheal and oropharyngeal swabs are the most appropriate sample types for this type of analysis as they do not contain organic material that may interfere with the reconstitution and amplification of the virus RNA as may be the case with cloacal swabs, faeces or intestinal contents (OIE, 2018). Studies have shown that sometimes the use of certain organs for QRT-PCR virus detection may fail if no precautions are taken during handling (Nanthakumar et al., 2000; Creelan et al., 2002; OIE, 2018). Terregino and capua describe several protocols used for genotyping and pathotyping of all APMV-1 lines, using specific samples such as allantoic fluid from embryonated poultry eggs or clinical samples (Terregino and Capua, 2013).

\section{In vivo and in vitro testing}

The virulence of Newcastle disease viruses can be experimented using in vivo and in vitro tests (Lancaster, 1981). The Intracerebral Pathogenicity Index (ICPI) in day-old chicks is the official test for measuring virulence. It is calculated after intracerebral 
infection of day-old chicks. A score (0: normal; 1: sick; 2: dead) is given to each chick daily for eight days. The average of these scores determines the virulence of the virus strain. Velogenic strains have an ICPI value above 1.5 and lentogenic strains have a value below 0.7. An ICPI value between 0.7 and 1.5 indicates the presence of a mesogenic strain.

The Intravenous Pathogenicity Index (IVPI) was calculated in a similar way as the ICPI but six weeks old birds were intravenously infected. An Intravenous Pathogenicity Index greater than 2.5 indicates the presence of a velogenic strain.

The Mean Death Time (MDT) is the average time, in hours, required for all inoculated embryos to die. Velogenic strains cause the death of embryos in less than 60 hours; however, when infected with lentogenic strains, embryos can survive beyond 90 hours (Alexander, 1988).

In vitro, the Newcastle disease virus induces the formation of plaques on culture of embryonic fibroblasts whose size and morphology vary according to the virulence of the viral strain.

\section{Disease control measures}

As with almost all avian viruses, there is no cure for Newcastle disease. The best control measure remains prevention and is mainly based on vaccination. It considerably reduces mortality, protects the birds and allows farmers to increase their income through sales. In regions where the disease is endemic, especially in developing countries, the measures put in place revolve around the following actions: systematic vaccination programme and improved biosecurity in commercial farms; regular vaccination of local free-range chickens; involvement of all stakeholders in vaccination and raising public awareness, strengthening diagnostic capacities. Vaccination programs vary according to regions and the animal health situation. In some countries such as Kenya, Ghana and Nigeria the vaccine is manufactured and available locally. Both live and inactivated vaccines are available for Newcastle disease. The virus strains used to manufacture conventional commercial vaccines are divided into two groups: Hitchner-B1, LaSota, V4, NDW, I2 strains which represent the lentogenic strains and Roakin, Mukteswar and Komarov strains which represent the mesogenic strains. Generally, live vaccines are made from viruses of lentogenic strains and mesogenic strains are used for the manufacture of inactivated vaccines. The OIE recommendation for the use of virus strains is that they should not have an intracerebral IPIC pathogenicity index greater than 0.7. It should be between 0.4 and 0.5 .

\section{Live vaccine}

Live vaccines are administered to birds by oral route, by coarse spray (aerosol) or by intranasal or conjunctival instillation. The immunity that these confer on chickens is weak and they must be administered twice at two to three week intervals with a booster after every three months. Live vaccines induce in chicks a high production of antibodies of the classes Immunoglobulin (IgA), Immunoglobulin Y (IgY) and Immunoglobulin M (IgM) in serum. In addition, by intraocular inoculation, these vaccines also induce the production of IgA in the Harder gland and IgM throughout the tear duct (Russell and Koch, 1993). Oral vaccination in hens induces cell-mediated immunity in the mucous membranes of the digestive tract (Ideris et al., 1990; Jayawardane and Spradbrow, 1995) due to the presence of Newcastle disease virus receptors in the digestive tract. The use of live vaccines in Newcastle disease control does not protect poultry from highly virulent ND outbreaks, which represents a big challenge (Capua et al., 2002).

\section{Inactivated vaccines}

In the manufacturing process of inactivated vaccines, formaldehyde or betapropiolactone is used to inhibit the pathogenicity of the virus. It is prepared from allantoic liquid and is incorporated in an emulsion with mineral or vegetable oil. Inactivated vaccines are administered to poultry by intramuscular or subcutaneous injection. This requires the handling of individual animals. In monetary terms, 
inactivated vaccines are more expensive than live vaccines. Inactivated vaccines are more effective in chickens that have previously received a live vaccine. Inactivated vaccines are usually done every six months (Getabalew et al., 2019).

\section{Constraints in controlling and eradicating the disease}

In rural areas and on small poultry farms with low numbers, compliance with good vaccination practices remains difficult. Most often in rural areas, it is very difficult to maintain the cold chain because the refrigerated storage system is deficient and an open vaccine can be used for several days. However, vaccines are thermolabile and must be kept at a temperature of $+4{ }^{\circ} \mathrm{C}$ to $10{ }^{\circ} \mathrm{C}$ until use at the risk of losing their effectiveness. Faced with this problem, solutions have been oriented towards the production of heat-stable vaccines. Vaccines with strains produced in Australia have been tested with relative success in Asia and Africa. However, their use remains limited. The administration of these thermotolerant vaccines is done by mixing them with chicken feed, most often cereals. In this situation, it is necessary to ensure that each chicken consumes a sufficient quantity of feed, which allows it to take the vaccine in an optimal way, giving it maximum protection against the virus. It is also necessary to thoroughly mix the vaccine with the cereals so that the cereals are well enveloped by the virus. In addition, vaccines are produced in large doses (Nwanta et al., 2008), which is of much greater benefit to commercial chicken producers who have large numbers of chickens of the same age and raise intensively.

The immunogenicity, the type (inactivated or live) and safety of vaccine are the main factors governing the choice of vaccine (Alexander, 2000). Several vaccines with suitable immunogenicity and safety are available for the control of ND in rural areas (Young et al., 2012). For successful vaccination campaigns in localities where access to the vaccine is difficult, Young et al. (2012) recommend to consider some factors such as; ease of transport, cost, previous experience in using vaccines, existing of veterinary services, the population distribution, and communications infrastructure when selecting a vaccine.

\section{Prospects for disease control and management}

The review has enabled us to identify three main areas from which we can identify solutions and effectively combat this disease. The first area is marker-assisted selection of myxovirus resistance genes ( $\mathrm{Mx}$ gene) in chickens. This is a promising avenue that deserves to be explored much further. Myxovirus resistance genes are found in several living organisms, including chickens (Haller et al., 2018). Mx proteins are interferon-induced guanosine triphosphate enzymes (GTPase) with antiviral functions, which play a particularly important role in the inhibition of RNA viruses with negative polarity. Marker-assisted selection of Newcastle disease virus resistant chickens is the promising solution. Studies have shown an association between the presence of this gene in certain breeds of chickens and resistance to Newcastle disease (Mpenda et al., 2019). The second is the modelling of the epidemiology of Newcastle disease. This will allow the collection of sufficient information to model the epidemic of Newcastle disease specific to each ecotype in order to adapt control measures to each region. Moreover, a more in-depth investigation on heat-stable vaccines would make it possible to support farmers in the fight against this disease. In addition, one of the factors limiting vaccine effectiveness is that vaccine strains are phylogenetically distant from circulating virulent strains, hence the importance of identifying the circulating strains in each region and producing vaccines that are genetically closer to the circulating strains in order to improve vaccine effectiveness. Some plants have also been tested for their antiviral properties on the virus. However, more in-depth studies still need to be conducted to provide more evidence on their effectiveness in the fight against the disease (Nyandoro et al., 2014; Nyandoro, 2017). Also according to Ezeibe et al. (2011), synthetic 
Aluminium Magnesium Silicate (AMS) would have antiviral effects on the Newcastle disease virus. Incubating this virus with AMS reduced significantly the viral titer and its morbidity in infected chick by natural mode of infection (Ezeibe et al., 2011).

\section{Socio-economic impact}

Newcastle disease is enzootic in Asia, Africa, the Middle East and some countries in Central and South America. Isolated outbreaks of Newcastle disease occur sporadically in some European countries. Its panzootic nature shows that it is a disease that knows no borders. The risk it represents concerns all countries. For example, during the second panzootic, 43; 3328; and 4217 outbreaks were identified in 1969; 1970; and 1971 respectively in England (Alexander et al., 2012). The impact of Newcastle disease is enormous in rural backyards and modern poultry farms. Family poultry farming is a means of improving food security and alleviating poverty (Nahimana et al., 2019). However, it is confronted with Newcastle disease, which decimates poultry flocks every year, especially in rural areas. The panzootic nature of Newcastle disease shows that it is a disease which has no borders. The risk it poses concerns all countries. Its economic impact can be assessed through the direct and indirect losses it causes. The direct losses are characterised by the mass deaths it causes. Indirect losses relate to morbidity, reduced egg production, weight losses, control measures, trade embargoes and bans on imports of poultry products from countries where the disease is present. In addition, it also represents a health hazard for humans. It can cause conjunctivitis when an individual is exposed to a large quantity of the virus. This is of particular concern to employees of livestock farms and laboratories (Yune and Abdela, 2017).

\section{CONCLUSION}

Newcastle disease represents a constant threat to the development of poultry farming, especially of the traditional type in developing countries. It is caused by an avian paramyxovirus type I (APMV-1). It is present on all continents. The only means of control in endemic areas remains vaccination. However, the practice of vaccination faces some obstacles that hinder the success of control measures and the eradication of the disease in rural areas. This review has highlighted three ways that represent prospects for the eradication of the disease.

\section{COMPETING INTERESTS}

The authors declare that they have no competing interests.

\section{AUTHORS' CONTRIBUTIONS}

KFXD: revue and drafting of the article. $\mathrm{ET}, \mathrm{KBB}$ and BBD: critical revision of the article and final approval of the version to be published.

\section{ACKNOWLEDGMENTS}

This study was supported by CERSA (Centre d'Excellence Régional sur les Sciences Aviaires) of the University of Lomé (Togo). The authors wish to express their warm gratitude to World Bank IDA 5424, who is the main sponsor of CERSA.

\section{REFERENCES}

Abdisa T, Tagesu T. 2017. Review on Newcastle Disease of Poultry and Its Public Health Importance. J. Vet. Sci. Technol., 08(03):1-7. DOI:10.4172/21577579.1000441.

Abdu PA, Tekdek LB, Umoh JU, Usman M, Oladele SB. 2007. Newcastle Disease in Nigeria. Niger. Vet. J., 27(2): 23-32. DOI:10.4314/nvj.v27i2.3512.

Agbede G, Demey F, Verhulst A, Bell JG. 1992. Prevalence of Newcastle Disease in Traditional Breeding Facilities for Chickens in Cameroon. Rev. Sci. Tech., 11(3): $\quad 805-811 . \quad$ DOI: 10.20506/rst.11.3.616.

Ahamed T, Hossain KM, Billah MM, Islam KMD, Ahasan MM, Islam ME. 2004. Adaptation of Newcastle Disease Virus (NDV) on Vero Cell Line. Int. J. Poult. Sci., $\quad 3(2)$ : $\quad 153-156$. DOI:10.3923/ijps.2004.153.156.

Aldous EW, Mynn JK, Banks J, Alexander DJ. 2003. A Molecular Epidemiological 
Study of Avian Paramyxovirus Type 1 (Newcastle Disease Virus) Isolates by Phylogenetic Analysis of a Partial Nucleotide Sequence of the Fusion Protein Gene. Avian Pathol., 32 (3): 239257.

DOI:10.1080/030794503100009783.

Alexander DJ. 1995. The Epidemiology and Control of Avian Influenza and Newcastle Disease. J. Comp. Pathol., 112(2): 105-126. DOI:10.1016/S00219975(05)80054-4.

Alexander DJ. 2000. Newcastle Disease and Other Avian Paramyxoviruses. OIE Rev. Sci. Tech., 19(2): 443-462. DOI:10.20506/rst.19.2.1231.

Alexander DJ, Aldous EW, Fuller CM. 2012. The Long View: A Selective Review of 40 Years of Newcastle Disease Research. Avian Pathol., 41(4):329-335. DOI:10.1080/03079457.2012.697991.

Alexander DJ, Senne DA. 2008. Newcastle Disease, Other Paramyxovirus and Pneumovirus Infectious. In Disease of Poultry (12 $2^{\text {th }}$ edn), Blackwell Publishing. Iowa.

Alexander DJ. 1988. Newcastle Disease Diagnosis. In Newcastle Disease $\left(1^{\text {st }}\right.$ edn). Part of the Developments in Veterinary Virology book series.

Allan WH, Lancaster JE, Toth B. 1980. L'hygiène dans la lutte contre la maladie de Newcastle. In Vaccin contre la maladie de Newcastle: production et utilisation. Volume 10 de collection FAO. Production et santé animale. 1-178.

Arbelot B, Dayan J, Mamis D, Gueye J, Tall F, Samb H. 1997. Enquête Sur La Prévalence Sérologique Des Principales Pathologies Aviaires Au Sénégal: Mycoplasmoses, Pullorose, Typhose, Maladie de Newcastle, Maladie de Gumboro et Bronchite Infectieuse. Rev. Elev. Med. Vet. Pays Trop., 50(3): 197203. ISSN: 0035-1865.

Bellini WJ, Englund G, Richardson CD, Rozenblatt S, Lazzarini RA. 1986. Matrix Genes of Measles Virus and Canine Distemper Virus: Cloning, Nucleotide Sequences, and Deduced Amino Acid Sequences. J. Virol., 58(2): 408-416. DOI:10.1128/jvi.58.2.408-416.1986.
Bossart KN, Fusco DL, Broder CC. 2013. Paramyxovirus Entry. Adv. Exp. Med. Biol., 790: 95-127. DOI:10.1007/978-14614-7651-1_6.

Bossart KN, Zhu Z, Middleton D, Klippel J, Crameri G, Bingham J, McEachern JA, Green D, Hancock TJ, Chan YP, Hickey AC, Dimitrov DS, Wang LF, Broder C. 2009. A Neutralizing Human Monoclonal Antibody Protects against Lethal Disease in a New Ferret Model of Acute Nipah Virus Infection. PLoS Pathog., 5(10): 111. DOI:10.1371/journal.ppat.1000642.

Brown J, Resurreccion RS, Dickson TG. 1990. The Relationship between the Hemagglutination-Inhibition Test and the Enzyme-Linked Immunosorbent Assay for the Detection of Antibody to Newcastle Disease. Avian Dis., 34(3): 585. DOI:10.2307/1591248.

Capua I, Dalla Pozza M, Mutinelli F, Marangon S, Terregino C. 2002. Newcastle disease outbreaks in Italy during 2000. Vet. Rec., 150(18): 565-568. Doi:10.1136/vr.150.18.565.

Chambers P, Millar NS, Platt SG, Emmerson PT. 1986. Nucleotide Sequence of the Gene Encoding the Matrix Protein of Newcastle Disease Virus. Nucleic Acids Res., $\quad$ 14(22): 9051-9061. DOI:10.1093/nar/14.22.9051.

Courtecuisse C, Japiot F, Bloch N, Diallo I. 1990. Serological Survey on Newcastle and Gumboro Diseases, Pasteurellosis and Pullorosis in Local Hens in Niger. Rev. Elev. Med. Vet. Pays Trop., 43(1): 27-29. ISSN: 0351865.

Courtney SC, Gomez D, Susta L, Hines N, Pedersen JC, Miller PJ, Afonso PL. 2012. Complete Genome Sequencing of a Novel Newcastle Disease Virus Isolate Circulating in Layer Chickens in the Dominican Republic. J. Virol., 86(17): 9550-9550. DOI:10.1128/jvi.01491-12.

Creelan JL, Graham DA, McCullough SJ. 2002. Detection and Differentiation of Pathogenicity of Avian Paramyxovirus Serotype 1 from Field Cases Using OneStep Reverse Transcriptase-Polymerase Chain Reaction. Avian Pathol., 31(5): 493-499.

DOI:10.1080/0307945021000005860. 
Czeglédi A, Ujvári D, Somogyi E, Wehmann E, Werner O, Lomniczi B. 2006. Third Genome Size Category of Avian Paramyxovirus Serotype 1 (Newcastle Disease Virus) and Evolutionary Implications. Virus Res., 120(1-2): 3648. DOI:10.1016/j.virusres.2005.11.009.

de Leeuw OS, Koch G, Hartog L, Ravenshorst N, Peeters BPH. 2005. Virulence of Newcastle Disease Virus Is Determined by the Cleavage Site of the Fusion Protein and by Both the Stem Region and Globular Head of the HaemagglutininNeuraminidase Protein. J Gen Virol., 86(6): 1759-1769. DOI:10.1099/vir.0.80822-0.

Diel DG, da Silva LHA, Liu H, Wang Z, Miller PJ, Afonso CL. 2012. Genetic Diversity of Avian Paramyxovirus Type 1: Proposal for a Unified Nomenclature and Classification System of Newcastle Disease Virus Genotypes. Infect Genet Evol., $\quad$ 12(8): $1770-1779$. DOI:10.1016/j.meegid.2012.07.012.

Doyle T M. 1927. A Hithero Unrecorded Disease of Fowls Due to a Filter-Passing Virus. J. Comp. Pathol. Therap., 40: 144169.

https://ci.nii.ac.jp/naid/20001280530/.

Ezeibe M, Ijabo O, Uzopuo C, Okoroafor O, Eze J, Mbuko I, Sanda M, Animoke P, Ngene A. 2011. Effects of AluminiumMagnesium Silicate on Newcastle Disease Virus and on recovery of infected chicks. Int. J. Biol. Chem. Sci., 5(2): 835- 839 .

DOI: 10.4314/ijbcs.v5i2.72160.

Ezeokoli CD, Umoh JU, Adesiyun AA, Abdu P. 1984. Prevalence of Newcastle Disease Virus Antibodies in Local and Exotic Chicken under Different Management Systems in Nigeria. Bulletin of Animal Health and Production in Africa., 32(3): 253-257. ISSN: 0378-9721.

Francis DW. 1973. Newcastle and Psittacines, 1970-1971. Poult Dig., 32: 16-19.

García-Sastre A, Cabezas JA, Villar E. 1989. Proteins of Newcastle Disease Virus Envelope: Interaction between the Outer Hemagglutinin-Neuraminidase Glycoprotein and the Inner NonGlycosylated Matrix Protein. Biochim.
Biophys Acta (BBA)/Protein Struct Mol., 999(2): 171-175. DOI:10.1016/01674838(89)90214-8.

Gear JHS. 1986. The History of Virology in South Africa. South African Med J., 70(10 SUPPL.): 7-10. ISSN: 00382469.

Getabalew M, Alemneh T, Akeberegn D, Getahun D, Zewdie D. 2019. Epidemiology, Diagnosis \& Prevention of Newcastle Disease in Poultry. Am $J$ Biomed Sci Res., 3(1): 50-59. DOI:10.34297/ajbsr.2019.03.000632.

Gotoh B, Komatsu T, Takeuchi K, Yokoo J. 2001. Paramyxovirus Accessory Proteins as Interferon Antagonists. Microbiol Immunol., $\quad \mathbf{4 5}(12)$ : 787-800. DOI:10.1111/j.13480421.2001.tb01315.x.

Grundler G, Schmidt M, Djabakou K.. 1988. Sérologie de La Maladie de Newcastle et de La Salmonellose (S. GallinarumPullorum) Chez Les Volailles Des Petites Exploitations Paysannes Au Togo. Rev. Elev. Med. Vet. Pays Trop., 41(4) 327328.

Gubareva LV., Penn CR, Webster RG. 1995. Inhibition of Replication of Avian Influenza Viruses by the Neuraminidase Inhibitor 4-Guanidino-2,4-Dideoxy-2,3Dehydro-N-Acetylneuraminic Acid. Virology., $\quad \mathbf{2 1 2}(2) \quad 323-330$. DOI:10.1006/viro.1995.1489.

Halle PD, Umoh JU, Sa'idu L, Abdu PA. 1999. Prevalence and Seasonality of Newcastle Disease in Zaria, Nigeria. Rev. Elev. Med. Vet. Pays Trop., 17: 53-62.

Haller O, Arnheiter H, Pavlovic J, Staeheli P. 2018. The discovery of the antiviral resistance gene Mx: A story of great ideas, great failures, and some success. Annu. Rev., Virol., 5(1): 33-51. DOI:10.1146/annurev-virology-092917043525.

Hamaguchi M, Nishikawa K, Toyoda T, Yoshida T, Hanaichi T, Nagai $Y$. Transcriptive Complex of Newcastle Disease Virus II. Structural and Functional Assembly Associated with the Cytoskeletal Framework. Virology., 147(2): 295-308. DOI:10.1016/00426822(85)90132-1.

Hanson RP, Spalatin P. 1978. Thermostability 
of the Hemagglutinin of Newcastle Disease Virus as a Strain Marker in Epizootiologic Studies. Avian. Dis., 22(4) 659-665. DOI:10.2307/1589642.

Hanson RP, Upton E, Brandly CA, Winslow NS. 1949. Heat Stability of Hemagglutinin of Various Strains of Newcastle Disease Virus. Proc Soc Exp Biol Med., $\quad 70 \quad$ (2) 283-287. DOI:10.3181/00379727-70-16899.

Ideris A, Ibrahim AL, Spradbrow PB. 1990. Vaccination of chickens against newcastle disease with a food pellet vaccine. Avian Pathol., 19(2): 371-384. Doi:10.1080/03079459008418687.

Hanson RP, Brandly CA 1955. Identification of vaccine strains of Newcastle disease virus. Science (New York, N.Y.)., 122(3160), 156-7. DOI:10.1126/science.122.3160.156-a.

Hernandez LD, Hoffman LR, Wolfsberg TG, White JM. 1996. Virus-cell and cell-cell fusion. Annu. Rev. Cell Dev Biol., 12(1): 621-661.

DOI:10.1146/annurev.cellbio.12.1.627.

Huang Y, Wan HQ, Liu HQ, Wu YT, Liu XF. 2004. Genomic Sequence of an Isolate of Newcastle Disease Virus Isolated from an Outbreak in Geese: A Novel Six Nucleotide Insertion in the Non-Coding Region of the Nucleoprotein. Gene. Arch. Virol., $\quad$ 149(7): 1445-1457. DOI:10.1007/s00705-004-0297-8.

Iwasaki M, Takeda M, Shirogane Y, Nakatsu Y, Nakamura T, Yanagi Y. 2009. The Matrix Protein of Measles Virus Regulates Viral RNA Synthesis and Assembly by Interacting with the Nucleocapsid Protein. J. Virol., 83(20): 10374-1038. DOI:10.1128/jvi.01056-09.

Jang J, Hong SH, Choi D, Choi KS, Kang S, Kim IH. 2010. Overexpression of Newcastle Disease Virus (NDV) v Protein Enhances NDV Production Kinetics in Chicken Embryo Fibroblasts. Appl. Microbiol. Biotechnol., 85(5) 15091520. DOI:10.1007/s00253-009-2189-z.

Jayawardane GWL, Spradbrow PB. 1995. Mucosal immunity in chickens vaccinated with the V4 strain of Newcastle disease virus. Vet. Microbiol., 46(1-3): 69-77. Doi:10.1016/0378-
1135(95)00073-J.

Kawano M, Bando H, Yuasa T, Kondo K, Tsurudome M, Komada H, Nishio M, Ito Y. 1990. Sequence Determination of the Hemagglutinin-Neuraminidase (HN) Gene of Human Parainfluenza Type 2 Virus and the Construction of a Phylogenetic Tree for HN Proteins of All the Paramyxoviruses That Are Infectious to Humans. Virology., 174 (1): 308-313. DOI:10.1016/0042-6822(90)90081-2.

Kho CL, Tan WS, Tey BT, Yusoff K. 2003. Newcastle Disease Virus Nucleocapsid Protein: Self-Assembly and LengthDetermination Domains. J. Gen. Virol., 84: 2163-2168. DOI:10.1099/vir.0.19107-0.

Kim S-H, Nayak S, Paldurai A, Nayak B, Samuel A, Aplogan GL, Awoume AA, Webby RJ, Ducatez MF, Collins PL, Samal SK. 2012. Complete Genome Sequence of a Novel Newcastle Disease Virus Strain Isolated from a Chicken in West Africa. J. Virol., 86 (20): 1139411395. DOI:10.1128/jvi.01922-12.

Kopecky SA, Lyles DS. 2003. Contrasting Effects of Matrix Protein on Apoptosis in HeLa and BHK Cells Infected with Vesicular Stomatitis Virus Are Due to Inhibition of Host Gene Expression. $J$. Virol., $\quad$ 77(8): 4658-4669. DOI:10.1128/jvi.77.8.4658-4669.2003.

Kraneveld FC. 1926. A Poultry Disease in the Dutch East Indies. Ned Indisch $\mathrm{Bl}$ Diergeneeskd., 38: 448-450.

Lamb RA, Kolakofsky D. 1996. Paramyxoviridae: The Viruses and Their Replication. In Fields Virology, Fields BN, Knipe DM (eds). Lippincott-Raven Press.

Lamb RA, Griffith D. 2001. Paramyxoviridae: The Viruses and Their Replication. In Fields Virology, Knipe DM, Howley PM, Griffin DF, Lamb RA, Malcolm AM, Roizman B, Straus SE (eds). Fields Virology.

Lancaster JE. 1975. Symposium on Viscerotropic Velogenic Newcastle Disease (V.V.N.D.) XV World's Poultry Congress, New Orleans, U.S.A. 1974 the summarizing presentation. Worlds. Poult. Sci., J., 31(3): $\quad 212-220$. 
DOI:10.1079/WPS19750016.

Lancaster JE. 1981. The Control of Newcastle Disease. Worlds. Poult. Sci. J., 37(2): 8496. DOI:10.1079/wps19810008.

Lefevre PC, Martel JL. 1975. Newcastle Disease in Ethiopia: Study of a Strain. Rev. Elev. Med. Vet. Pays Trop., 28(3): 283-286. DOI:10.19182/remvt.7995.

Locke DP, Sellers HS, Crawford JM, SchultzCherry S, King DJ, Meinersmann RJ, Seal BS. 2000. Newcastle Disease Virus Phosphoprotein Gene Analysis and Transcriptional Editing in Avian Cells. Virus Res., 69(1): 55-68. DOI:10.1016/S0168-1702(00)00175-1.

Maho A, Ndeledje Gondje N, Mopate LY, Kana G. 2004. La Maladie de Newcastle Au Sud Du Tchad: Périodes de Pic Épidémique et Impact de La Vaccination. OIE Rev. Sci. Tech., 23(3): 777-782. DOI:10.20506/rst.23.3.1520.

Maminiaina OF. 2011. Caractérisation Des Virus de La Maladie de Newcastle (APMV-1), Circulant Sur Les Hautes Terres de Madagascar. PhD thesis Universite d'Antananarivo, Madagascar, p 215.

Manchang T, Abdu P, Saidu L. 2004. Epidemiology and Clinicopathologic Manifestations of Newcastle Disease. Rev. Elev. Med. Vet. Pays Trop., 57 (12): 35-39.

Miller PJ, Koch G. 2013. Newcastle Disease. In Disease of Poultry, Glisson JR, McDougald LR, Nolan LK, Suarez DL, Nair VL (eds). Ames, IA:WileyBlackwell in partnership with the American Association of Avian Pathologists. 89-138.

Minga UM, Katule A, Maeda T, Musasa J. 1989. Potential and Problems of the Traditional Chicken Industry in Tanzania. In Proceedings of the 7th TVA Scientific Conference. Tanzania Veterinary Association, Arusha, Tanzania, 207-215. Mpenda FN, Keambou CT, Kyallo M, Pelle R, Lyantagaye SL, Buza J. 2019. Polymorphisms of the Chicken Mx Gene Promoter and Association with Chicken Embryos Susceptibility to Virulent Newcastle Disease Virus Challenge. BioMed Res. Int., 2019: 1-7.
DOI:10.1155/2019/1486072.

Nagai Y, Klenk HD, Rott R. 1976. Proteolytic Cleavage of the Viral Glycoproteins and Its Significance for the Virulence of Newcastle Disease Virus. Virology., 72(2): 494-508. DOI:10.1016/00426822(76)90178-1.

Nahimana G, Ossebi W, Missohou A. 2019. Analyse de l'importance socioéconomique de l'aviculture familiale dans le Département de Salemata au Sénégal. Int. J. Biol. Chem. Sci., 13(7): 3131-3143. DOI:10.4314/ijbcs.v13i7.13.

Nanthakumar T, Kataria RS, Tiwari AK, Butchaiah G, Kataria JM. 2000. Pathotyping of Newcastle Disease Viruses by RT-PCR and Restriction Enzyme Analysis. Vet. Res. Commun., 24(4):275-86. DOI:10.1023/A:1006403017578.

Nwanta JA, Abdu PA, Ezema WS. 2008. Epidemiology, Challenges and Prospects for Control of Newcastle Disease in Village Poultry in Nigeria. Worlds. Poult. Sci. $\quad J ., \quad \mathbf{6 4}(1)$ : $\quad 119-127$. DOI:10.1017/S0043933907001766.

Nyandoro S, Nkunya M, Cosam J, Msoffe P, 2014. In ovo antiviral potency of the leaf constituents of Tanzanian Toussaintia species against Infectious Bursal Disease Virus and Newcastle Disease Virus. Int. J. Biol. Chem. Sci., 8(3): 1308. DOI: 10.4314/ijbcs.v8i3.43

Nyandoro S. 2017. In ovo antiviral activity of the constituents of Artabotrys monteiroae and Artabotrys modestus against Infectious Bursal Disease and Newcastle Disease Viruses. Int. J. Biol. Chem. Sci., 11(6): $\quad 3075-3085 . \quad$ DOI: 10.4314/ijbcs.v11i6.41.

Ogasawara T, Gotoh B, Suzuki H, Asaka J, Shimokata K, Rott R, Nagai Y. 1992. Expression of Factor $\mathrm{X}$ and Its Significance for the Determination of Paramyxovirus Tropism in the Chick Embryo. EMBO J., 11(2): 467-472. DOI:10.1002/j.14602075.1992.tb05076.x.

OIE. 2014. Newcastle disease: Aetiology Epidemiology Diagnosis Prevention and Control References. World Organ. Anim. Heal., 1: 1-5. 
OIE. 2018. Manual of Diagnostic Tests and Vaccines for Terrestrial Animals. In OIE Terrestrial Manual 2018. OIE.

OIE. 2020. OIE World Animal Health Information System. Weekly Animal Disease Sevice Global Report. https://www.oie.int/wahis_2/public/wahi d.php/Countryinformation/Animalsituati on.

Orajaka L, Adene D, Anene B, Onuoha E. 1999. Seroprevalence of Newcastle Disease in Local Chickens from Southeast Derived Savannah Zone of Nigeria. Rev. Elev. Med. Vet. Pays Trop., 52(3): 185-188. ISSN: 0035-1865.

Pan African Animal Resources. 2013. Pan African Animal Resources Yearbook. Pan African Animal Resources Yearbook. 2013: 104.

Panda A, Huang Z, Elankumaran S, Rockemann DD, Samal SK. 2004. Role of Fusion Protein Cleavage Site in the Virulence of Newcastle Disease Virus. Microb. Pathog., 36(1): 1-10. DOI:10.1016/j.micpath.2003.07.003.

Peeters BPH, Gruijthuijsen YK, De Leeuw OS, Gielkens ALJ. 2000. Genome Replication of Newcastle Disease Virus: Involvement of the Rule-of-Six. Arch. Virol., 145(9) 1829-1845.

DOI:10.1007/s007050070059.

Peeters BPH, de Leeuw OS, Koch G, Gielkens ALJ. 1999. Rescue of Newcastle Disease Virus from Cloned CDNA: Evidence That Cleavability of the Fusion Protein Is a Major Determinant for Virulence. $J$. Virol., $\quad \mathbf{7 3}(6) \quad$ 5001-5009. DOI:10.1128/jvi.73.6.5001-5009.1999.

Qosimah D, Murwani S, Sudjarwo E, Arfan Lesmana M. 2018. Effect of Newcastle Disease Virus Level of Infection on Embryonic Length, Embryonic Death, and Protein Profile Changes. Vet World., 11(9): 1316-1320. DOI: 10.14202/vetworld.2018.1316-1320.

Rajaonarison J. 1991. Note sur la maladie des volailles tout nouvellement observé à Madagascar. In Production de vaccin contre la maladie de Newcastle à Madagascar.

Rauw F, Gardin Y, van den Berg T, Lambrecht B. 2009. La Vaccination Contre La
Maladie de Newcastle Chez Le Poulet (Gallus Gallus). Biotechnol. Agron. Soc. Environ., 13(4) 587-596.

Römer-Oberdörfer A, Werner $\mathrm{O}$, Veits $\mathrm{J}$, Mebatsion T, Mettenleiter TC. 2003. Contribution of the Length of the HN Protein and the Sequence of the F Protein Cleavage Site to Newcastle Disease Virus Pathogenicity. J. Gen. Virol., 84(11): 3121-3129. DOI:10.1099/vir.0.19416-0.

Roy P. 2012. Diagnosis and Control of Newcastle Disease in Developing Countries. Worlds. Poult. Sci. J., 68(04): 693-706.

DOI:10.1017/S0043933912000827.

Russell PH, Koch G. 1993. Local antibody forming cell responses to the Hitchner B1 and Ulster strains of Newcastle disease virus. Vet. Immunol. Immunopathol., 37(2) 165-180. Doi:10.1016/01652427(93)90063-A.

Scheid A, Choppin PW. 1974. The Hemagglutinating and Neuraminidase Protein of a Paramyxovirus: Interaction with Neuraminic Acid in Affinity Chromatography. Virology., 62(1): 125133. DOI:10.1016/0042-6822(74)90308-0.

Seal BS, Wise MG, Pedersen JC, Senne DA, Alvarez R, Scott MS, King DJ, Yu Q, Kapczynski DR. 2005. Genomic Sequences of Low-Virulence Avian Paramyxovirus-1 (Newcastle Disease Virus) Isolates Obtained from Live-Bird Markets in North America Not Related to Commonly Utilized Commercial Vaccine Strains. Veterinary Microbiology., 106(12): 7-16. DOI: 10.1016/j.vetmic.2004.11.013.

Seth S, Skountzou I, Gernert KM, Compans RW. 2007. Fusogenic Variants of a Noncytopathic Paramyxovirus. J. Virol., 81(8): $\quad 4286-4297 . \quad$ DOI: 10.1128/jvi.01623-06.

Smith EC, Popa A, Chang A, Masante C, Dutch RE. 2009. Viral Entry Mechanisms: The Increasing Diversity of Paramyxovirus Entry. FEBS J., 276(24): 7217-7227. DOI:10.1111/j.1742-4658.2009.07401.x.

Spradbrow PB. 1992. Newcastle Disease in Village Chickens Control with Thermostable Oral Vaccines. In Proceedings of an International 
Workshop Held in Kuala Lumpur, Malaysia 6-10 October 1991., (39): 1185.

Suzuki M, Suzuki A, Yamakawa T, Matsunaga E. 1985. Characterization of 2,7Anhydro-N-Acetylneuraminic Acid in Human Wet Cerumen. J. Biochem., 97(2): $509-515 . \quad$ DOI: 10.1093/oxfordjournals.jbchem.a135085.

Swayne DE, King DJ. 2003. Avian Influenza and Newcastle Disease. J. Am. Vet. Med. Assoc., $\quad$ 222(11): $\quad 1534-1540$. DOI:10.2460/javma.2003.222.1534.

Tashiro M, Yokogoshi Y, Tobita K, Seto JT, Rott R, Kido H. 1992. Tryptase Clara, an Activating Protease for Sendai Virus in Rat Lungs, Is Involved in Pneumopathogenicity. J. Virol., 66(12) 7211-7216. DOI:10.1128/jvi.66.12.72117216.1992.

Terregino C, Capua I. 2013. Méthode Conventionnelle de Diagnostic de l'infection Par Le Virus de La Maladie de Newcastle. In Influenza Aviaire et Maladie de Newcastle., Springer Paris. 129-131. DOI:10.1007/978-2-28799337-4_10.

Utterback WW, Schwartz JH. 1973. Epizootiology of Velogenic Viscerotropic Newcastle Disease in Southern California, 1971-1973. J. Am. Vet. Med. Assoc., 163(9): 1080-1088.

Von Itzstein M, Wu WY, Kok GB, Pegg MS, Dyason JC, Jin B, Smythe ML, White HF, Oliver SW, Colman PM, Varghese JN, Ryan DM, Woods JM, Bethell RC, Hotham VJ, Cameron JM, Penn CR. 1993. Rational Design of Potent Sialidase-Based Inhibitors of Influenza Virus Replication. Nature., 363(6428): 418-423. DOI:10.1038/363418a0.

Walker JW, Heron BR, Mixson MA. 1973. Exotic Newcastle Disease Eradication
Program in the United States. Avian Dis., 17(3): 486. DOI: $10.2307 / 1589147$.

Whelan SPJ, Barr JN, Wertz GW. 2004. Transcription and Replication of Nonsegmented Negative-Strand RNA Viruses. In Biology of Negative Strand RNA Viruses: The Power of Reverse Genetics, Kawaoka Y (ed). Springer Verlag.

Yamakawa I, Tsurudome M, Kawano M, Nishio M, Komada H, Ito M, Uji Y, Ito Y. 2007. Failure of Multinucleated Giant Cell Formation in K562 Cells Infected with Newcastle Disease Virus and Human Parainfluenza Type 2 Virus. Microbiol. Immunol., 51(6): 601-608. DOI:10.1111/j.13480421.2007.tb03946.x.

Youn JL, Haan WS, Jun GC, Jae HK, Chang SS. 2004. Molecular Epidemiology of Newcastle Disease Viruses Isolated in South Korea Using Sequencing of the Fusion Protein Cleavage Site Region and Phylogenetic Relationships. Avian Pathol., $\quad$ 33(5): $\quad 482-491$. DOI: $10.1080 / 03079450400003700$.

Young M, Alders R, Grimes S, Spradbrow P, Dias P, da Silva A, Lobo Q. 2012. Le Contrôle de la Maladie de Newcastle chez. les Poulets de Village: un Manuel de Laboratoire ( $2^{\mathrm{ème}}$ edn). Monographie ACIAR Centre Australien International pour la Recherche Agricole: Canberra.

Yune N, Abdela N. 2017. Update on Epidemiology, Diagnosis and Control Technique of Newcastle Disease. J. Vet. Sci. Technol., $\quad \mathbf{8}(2): \quad 1-6$. DOI:10.4172/2157-7579.1000429.

Yusoff K, Wen Siang Tan. 2001. Newcastle Disease Virus: Macromolecules and Opportunities. Avian Pathol., 30(5): 439455. DOI:10.1080/03079450120078626. 